\title{
KONTRIBUSI UNIT USAHA DALAM MEWUJUDKAN PERPUSTAKAAN SEBAGAI PUBLIC SPHERE DI PERPUSTAKAAN UNISSULA - SEMARANG
}

\author{
Ika Krismayani ${ }^{1^{*}}$ \\ ${ }^{1}$ Program Studi Ilmu Perpustakaan, Fakultas Ilmu Budaya, Universitas Diponegoro \\ *Korespondensi: ika.krismayani@live.undip.ac.id
}

Diajukan: 13-12-2019; Direview: 20-01-2020; Diterima: 29-08-2020; Direvisi: 13-09-2020

\begin{abstract}
This study aims to identify and analyze the contribution of business units in realizing the library as a public sphere in the Unissula library. Specifically, the business unit studied was the canteen in the Unissula library. The research method used in this research is descriptive qualitative research method. The results showed that the business unit (i.e. canteen) in the Unissula library was considered to be a place for the realization of public sphere for the users. The location of the canteen which is close to the services in the library makes users feel free to chat with other users on the sidelines of utilizing the existing services of the Unissula library. The design of the canteen by providing adequate tables and chairs also makes users comfortable in meetings, discussions and interactions with other users.
\end{abstract}

\begin{abstract}
ABSTRAK
Penelitian ini secara khusus bertujuan untuk mengidentifikasi dan menganalisa kontribusi unit usaha dalam mewujudkan perpustakaan sebagai public sphere di perpustakaan Unissula. Secara khusus, unit usaha yang dikaji adalah kantin yang terdapat di perpustakaan Unissula. Metode penelitian yang digunakan dalam penelitian ini adalah metode penelitian deskriptif kualitatif. Hasil penelitian menunjukkan bahwa unit usaha berupa kantin yang ada di perpustakaan Unissula dianggap menjadi tempat terwujudnya public sphere bagi pemustaka. Letak kantin yang dekat dengan layanan yang ada di perpustakaan membuat pemustaka merasa leluasa untuk saling mengobrol dengan pemustaka lain di sela-sela memanfaatkan layanan yang ada perpustakaan Unissula. Desain kantin dengan penyediaan meja dan kursi yang memadai juga membuat pemustaka nyaman dalam bertemu, berdiskusi dan berinteraksi dengan pemustaka lain.
\end{abstract}

Keywords: Academic library; Business unit; Public sphere; Library services; User activity

\section{PENDAHULUAN}

Masyarakat Indonesia mengenal lima jenis perpustakaan yang disesuaikan dengan target pemustaka dan fungsinya. Mengacu pada Undang-Undang No.43 Tahun 2007 tentang Perpustakaan ada lima jenis perpustakaan yaitu: perpustakaan nasional, perpustakaan umum, perpustakaan sekolah, perpustakaan perguruan tinggi, dan perpustakaan khusus. Keberadaan perpustakaan merupakan suatu kebutuhan bagi masyarakat maupun instansi. Salah satunya keberadaan perpustakaan di Perguruan Tinggi, perpustakaan dapat dikatakan sebagai pusat kegiatan sivitas akademika yang memiliki kebutuhan informasi lebih kompleks karena terdiri dari dosen, mahasiswa, dan peneliti.

Sebagai penunjang perkuliahan dan penelitian, keberadaan perpustakaan diharuskan dapat memenuhi kebutuhan informasi yang dimiliki oleh sivitas akademika. Meskipun pustakawan telah berusaha untuk memenuhi segala kebutuhan akan referensi kuliah dan penelitian, pustakawan perguruan tinggi juga memiliki tantangan dalam bertugas. Pustakawan tidak hanya menyediakan koleksi yang sesuai dengan kebutuhan pemustaka, tetapi juga dituntut untuk dapat menciptakan area publik atau public sphere. Menurut Ariyani (2015) konsep public sphere dapat merujuk pada pendapat Habermas yakni sebagai sebuah ruang yang terbentuk melalui hasil interaksi dan komunikasi sosial. Mengacu konsep tersebut, perpustakaan dituntut untuk mampu menjadi tempat untuk bertemu atau sebagai pusat pertemuan masyarakat. 
Sebagai upaya mewujudkan public sphere di perpustakaan, berbagai macam inovasi telah banyak diterapkan oleh perpustakaan perguruan tinggi. Sebagaimana yang terlihat di Perpustakaan ITS telah tersedia ruang publik di perpustakaan, yang disebut sebagai Wifi Zone Corner (Qomariyah \& Rahmi, 2017). Keberadaan area hotspot disertai dengan adanya kegiatan jual beli menjadi salah satu rancangan ruang publik di perpustakaan yang menarik (Dewi, 2011). Berdasarkan pada kegiatan yang dimiliki oleh mahasiswa, inovasi tersebut tidak hanya dapat membantu mahasiswa dalam memenuhi kebutuhan belajarnya, tetapi juga dapat menjadikan perpustakaan sebagai meeting point berbagai elemen mahasiswa dalam rangka ajang bertukar ide dan pembelajaran.

Public sphere di perpustakaan tidak hanya menyangkut hanya akses informasi saja, tetapi juga kebutuhan lain seperti kenyamanan, tempat bersantai, makan dan minum pemustaka juga perlu diperhatikan. Untuk memenuhi kebutuhan tersebut pustakawan telah berusaha membuat inovasi dengan menyediakan beberapa unit usaha, salah satunya kantin di lingkungan perpustakaan perguruan tinggi. Tersedianya kantin juga didukung oleh faktor eksternal, yaitu mengenai kondisi cuaca lingkungan sekitar seperti di wilayah Semarang - yang memiliki kondisi cuaca relatif panas yang membuat mahasiswa akan lebih membutuhkan makan dan minum setelah atau sebelum beraktivitas.

Salah satu perpustakaan perguruan tinggi yang memiliki fasilitas kantin di lingkungan perpustakaan, yaitu Perpustakaan Universitas Islam Sultan Agung (Unissula) Semarang. Lokasi universitas yang berada di dekat pantai dan memiliki kondisi lingkugan yang panas serta lalu lintas yang padat menyebabkan mahasiswa lebih membutuhkan energi. Untuk memberikan fasilitas yang menunjang mahasiswa dalam belajar, pustakawan telah berusaha mendirikan kantin di Perpustakaan Unissula.

Berdasarkan observasi awal yang dilakukan oleh penulis, keberadaan kantin menjadi daya tarik bagi pemustaka yang notabene mahasiswa. Kantin yang ada di Perpustakaan Unissula selalu ramai dikunjungi oleh pemustaka untuk memenuhi kebutuhan makan dan minum, mereka juga banyak yang melakukan diskusi di kantin perpustakaan tersebut. Hal tersebut lantaran letak kantin cukup dekat dengan ruang referensi. Hal inilah yang kemudian menarik minat penulis untuk melakukan kajian lebih lanjut.

\section{TINJAUAN PUSTAKA}

Layanan perpustakaan merupakan salah satu daya tarik pemustaka untuk mengunjungi perpustakaan. Selain layanan, fasilitas yang mendukung pembelajaran pun dapat menjadi daya tarik tersendiri bagi pemustaka (Hasanah, 2013). Melalui daya tarik yang ada, perpustakaan diharapkan mampu berfungsi sebagai ruang bertemunya berbagai tipe masyarakat guna bertukar ide, gagasan sebagai bentuk demokratisasi ilmu pengetahuan. Pada tahap inilah, perpustakaan berubah tidak hanya menyediakan informasi, tetapi juga menjadi public sphere yang dapat dimanfaatkan oleh seluruh lapisan masyarakat.

Sumaryanto (2008) mengatakan bahwa perpustakaan memiliki potensi yang kuat untuk menjadi public sphere. Menurutnya, potensi pertama yang dimiliki oleh perpustakaan adalah independensi dalam mengelola informasi yang tersedia. Potensi kedua, perpustakaan juga mampu menjadi ruang yang bersifat demokratis melalui penyediaan koleksi untuk dibaca, dipelajari, dan ditanggapi sehingga mampu mengkonstruksi pengetahuan baru. Potensi terakhir yang dimiliki oleh perpustakaan adalah adanya usaha untuk menyediakan layanan sesuai dengan kebutuhan pemustakanya. Melihat hal tersebut, pengelola perpustakaan perlu melakukan berbagai inovasi.

Inovasi dalam menyediakan unit usaha yang dapat dimanfaatkan mahasiswa, merupakan langkah tepat karena dapat digunakan oleh pemustaka untuk saling berinteraksi untuk memanfaatkan layanan perpustakaan dan unit usaha yang tersedia. Meskipun perpustakaan 
merupakan lembaga nonprofit, namun perpustakaan perlu memikirkan bagaimana membangun unit usaha sebagai sebuah inovasi dalam menciptakan public sphere di perpustakaan. Opara (2012) mengatakan bahwa perpustakaan perlu menciptakan aktivitas wirausaha sebagai salah satu inovasi di perpustakaan. Arya (2011) mengatakan hal tersebut sebagai bentuk metamorfosa perpustakaan dari lembaga non profit sector menjadi incoming generating unit.

Salah satu inovasi unit usaha yang marak diterapkan di perpustakaan adalah dengan menyediakan kafe atau kantin di perpustakaan. Keberadaan kafe atau kantin di perpustakaan merupakan wujud perpaduan antara aspek bisnis dengan aspek nonprofit (Istiarni \& Triningsih, 2019). Keberadaan unit usaha berupa kafe atau kantin dapat digunakan untuk memfasilitasi mahasiswa agar dapat beristirahat sejenak setelah kuliah. Adanya kantin dapat menjadikan perpustakaan sebagai public sphere yang dapat dimanfaatkan oleh pemustaka sembari menggunakan fasilitas layanan perpustakaan lainnya.

Kajian terkait public sphere di perpustakaan masih jarang yang mengkaitkannya dengan unit usaha di perpustakaan. Qomariyah \& Rahmi (2017) mengatakan bahwa perpustakaan dapat menciptakan public sphere. Menurutnya, salah satu usaha dalam menciptakan ruang tersebut adalah dengan menyediakan fasilitas Wifi Corner. Hal yang sama juga dikatakan Nasrullah (2012) bahwa internet merupakan salah satu bentuk ruang publik dalam wujud virtual. Muttaqin (2010) menambahkan bahwa penggabungan aspek wirausaha dengan dunia perpustakaan dalam menciptakan public sphere. Menurutnya, keberadaan dunia wirausaha dalam bentuk angkringan mampu menciptakan perpustakaan yang merakyat serta public sphere dan ruang diskusi yang sehat di perpustakaan.

Penggabungan unit usaha di perpustakaan saja tidak cukup untuk menciptakan public sphere. Perlu dilakukan kajian terkait kontribusi atau keberhasilan unit usaha tersebut dalam menciptakan perpustakaan sebagai public sphere. Qomariyah \& Rahmi (2017), terdapat beberapa indikator kunci dalam mengukur public sphere di perpustakaan, yaitu mudah diakses, keseimbangan layanan kepada pemustaka, nyaman dan bercitra baik, serta tempat bersosialisasi. Indikator tersebut dapat digunakan untuk mengkaji bagaimana kesuksesan unit usaha dalam mewujudkan perpustakaan sebagai public sphere.

\section{METODE}

Penelitian ini menggunakan metode kualitatif - deskriptif, penelitian deskriptif merupakan penelitian yang terjadi pada saat sekarang (Muhtadien, 2017). Peneliti menggunakan metode kualitatif untuk mengungkap kontribusi keberadaan unit usaha dalam mewujudkan perpustakaan sebagai public sphere di Perpustakaan Unissula Semarang. Penggunaan metode kualitatif agar peneliti dapat memahami lebih dalam situasi yang terjadi di lapangan terkait adanya fasilitas kantin. Untuk memaknai lebih dalam kondisi yang terjadi di lapangan, peneliti akan mengkaji lebih dalam informasi yang disampaikan oleh informan secara personal.

Untuk mendapatkan informasi yang dibutuhkan, peneliti akan melakukan pengambilan data melalui teknik wawancara dan studi literatur. Informasi yang telah didapat selanjutnya akan dianalisa dan diverifikasi untuk dapat ditarik kesimpulan secara mendalam. Penentuan informan pada penelitian ini menggunakan purposive sampling. Sugiyono (2009) menyatakan purposive sampling merupakan penentuan sampel informan dengan pertimbangan tertentu. Informan dalam penelitian ini berjumlah 6 orang mahasiswa, yang berasal dari berbagai program studi yang berbeda. Peneliti melakukan wawancara kepada informan yaitu mahasiswa yang terlihat sedang memanfaatkan unit usaha di Perpustakaan Unissula. Informan tersebut dibutuhkan peneliti untuk memberikan informasi yang diperlukan dari mahasiswa sebagai pengguna fasilitas berupa unit usaha di perpustakaan. 


\section{HASIL DAN PEMBAHASAN}

\subsection{Unit Usaha di Perpustakaan Unissula}

Perpustakaan pada dasarnya merupakan lembaga nonprofit yang tidak mengambil keuntungan atas pelayanan yang diberikan kepada pemustaka. Meskipun demikian, berdasarkan UU No.43 Tahun 2007 tentang Perpustakaan, tidak menutup kemungkinan bagi perpustakaan untuk memperoleh sumber pendanaan atas usaha yang mereka lakukan. Keberadaan unit usaha di perpustakaan memang masih menjadi perdebatan. Hal ini menjadikan tidak semua perpustakaan memiliki unit usaha. Kondisi tersebut juga dirasakan oleh beberapa informan. Keberadaan unit usaha di perpustakaan merupakan hal yang baru bagi mereka. Beberapa informan menjawab bahwa mereka belum mengetahui adanya unit usaha di perpustakaan.

Ketika diberikan pertanyaan terkait unit usaha di perpustakaan, beberapa diantara informan mengaku belum pernah mendengar. Hal tersebut sebagaimana diungkapkan oleh informan 4. Istilah unit usaha masih asing bagi informan tersebut “... saya belum pernah...”. Hal serupa juga diungkapkan oleh beberapa informan lainnya. Salah satu informan masih belum dapat membedakan antara pelayanan dengan unit usaha. Informan 1 mengungkapkan “...belum, kalau unit itu seperti apa bentuk pelayanannya..." Pernyataan tersebut menunjukkan bahwa keberadaan unit usaha di perpustakaan memang masih asing bagi beberapa informan.

Hal yang berbeda diungkapkan oleh informan 3 dan 5. Menurutnya, mereka pernah mendengar istilah tersebut. Menurut informan 3, salah satu bentuk unit usaha adalah kegiatan untuk menjual barang kepada konsumen. “...seperti kita membuat usaha, menjual barang ke konsumen...”. Hal tersebut dikatakan oleh informan 5 bahwa keberadaan kantin di perpustakaan merupakan bentuk dari kegiatan unit usaha di Perpustakaan Unissula.

Sebagian informan sependapat bahwa mereka telah memanfaatkan unit usaha yang ada di perpustakaan. Mereka mengaku pernah memanfaatkan unit usaha seperti kantin maupun layanan fotokopi di perpustakaan. Hal ini menunjukkan bahwa keberadaan unit usaha di perpustakaan masih perlu dipromosikan lagi. Meskipun keberadaan unit usaha di perpustakaan belum banyak diketahui oleh pemustaka, namun mereka telah memanfaatkan hal tersebut.

\subsection{Pemanfaatan Unit Usaha di Perpustakaan Unissula}

Perpustakaan Unissula menyediakan dua jenis unit usaha, yaitu usaha fotokopi dan kantin. Usaha fotokopi disediakan bagi pemustaka yang membutuhkan untuk memfotokopi koleksi yang dibaca dengan peraturan tertentu. Selain itu, pada usaha ini juga terdapat jasa cetak dokumen. Sedangkan usaha kantin disediakan bagi pemustaka yang ingin menikmati makanan sembari membaca di perpustakaan.

Intensitas pemanfaatan unit usaha di Perpustakaan Unissula berbeda-beda menurut informan. Usaha fotokopi dan print merupakan unit usaha yang paling sering dimanfaatkan. Sebagaimana dikatakan oleh Informan 1, bahwa “...pemustaka lebih sering memfotokopi dan nge-print tugas...”, Pernyataan serupa disampaikan oleh Informan 3 bahwa “...saya ke perpustakaan untuk memfotokopi dan nge-print, lebih dekat, apalagi yang dari fakultas ekonomi jika ingin nge-print skripsi atau tugas, mereka datang ke sini...".

Kantin merupakan unit usaha lain yang tersedia dan dapat dimanfaatkan oleh pemustaka ketika berkunjung di perpustakaan. Namun intensitas pemanfaatan unit usaha ini lebih kecil dibandingkan dengan pemanfaatan unit usaha fotokopi. Menurut informan, kantin bermanfaat bagi pemustaka, namun dikarenakan terdapat kantin lain yang lebih dekat dengan fakultas tempat mereka kuliah, maka mereka lebih sering memanfaatkan kantin di sekitar fakultas daripada kantin perpustakaan. Pemanfaatan kantin perpustakaan hanya dilakukan ketika mereka sedang berkunjung di perpustakaan. Sebagaimana yang dikatakan Informan 2 bahwa “...kalau sedang ke perpustakaan, 
saya juga makan di sana...". Hal tersebut menunjukkan bahwa lokasi unit usaha yang strategis mampu mendorong mahasiswa untuk memanfaatkan unit usaha tersebut.

\subsection{Public Sphere dalam Pandangan Mahasiswa}

Istilah public sphere seringkali dikaitkan Habermas (Widdersheim, 2017). Dalam hal ini, perpustakaan dituntut untuk mampu menciptakan ruang publik sebagai ruang komunikasi dan aktivitas sosial lainnya (Krismayani, 2016). Meskipun erat dengan perpustakaan umum, namun dalam prakteknya konsep public sphere dapat diterapkan pada berbagai jenis perpustakaan.

Setiap informan memiliki penafsiran yang hampir sama terhadap istilah public sphere. Secara umum, mereka menganggap istilah tersebut berkaitan dengan pemanfaatan ruang publik bagi masyarakat umum. Informan 1 menyatakan “... ruangan dapat dipakai untuk umum... ”. Hal serupa juga diungkapkan oleh informan 4 , bahwa “...public sphere, seperti tempat umum bukan sih...?”

Terkait pemanfaatannya, informan menganggap bahwa public sphere merupakan tempat yang dapat digunakan untuk saling berbagi. Informan 2 mengatakan bahwa "...seperti ruang untuk berbagi kan? untuk sharing..." Hal serupa juga diungkapkan oleh informan 6. Menurutnya, public sphere merupakan ruang yang dapat dimanfaatkan untuk diskusi dan menikmati bahan bacaan.

“...tempatnya tidak terbuka dan tertutup, tetapi seperti tempat diskusi, dan kita dapat membaca di situ...".

Selain sebagai tempat berbagi dan berdiskusi, informan menganggap bahwa public sphere dapat digunakan untuk menyampaikan aspirasi. Sebagaimana dikatakan Informan 4 bahwa “...public sphere merupakan ruang publik atau tempat umum untuk mengeluarkan aspirasi...". Informan sepakat bahwa public sphere merupakan ruang publik yang dapat dimanfaatkan untuk aktifitas sosial seperti berbagi pengetahuan, diskusi, dan menyampaikan aspirasi.

\subsection{Kontribusi Unit Usaha untuk Public Sphere di Perpustakaan Unissula}

Sebagaimana dijelaskan di atas bahwa perpustakaan adalah 'ruang publik' yang dapat dijadikan sebagai tempat bertemu oleh pemustaka, dan mereka dapat berinteraksi satu sama lain. Public sphere di perpustakaan diharapkan mampu mendekatkan diri pemustaka dengan informasi yang dikelola oleh perpustakaan, serta menyediakan informasi untuk keperluan aktivitas social pemustaka. Berdasarkan hasil wawancara, ada beberapa hal atau fasilitas unit usaha untuk mendukung terwujudnya perpustakaan sebagai public sphere.

\section{1) Meeting point}

Mahasiswa zaman sekarang banyak yang mengerjakan tugas kuliah dengan mencari tempat yang nyaman dan dekat dengan informasi yang mereka butuhkan untuk mendukung pekerjaan dan tugas kuliah. Kebutuhan mahasiswa dalam mengerjakan tugas meliputi kebutuhan informasi dan kebutuhan suplay makanan dan minuman, sehingga ketika mengerjakan tugas, mereka dapat makan dan minum di perpustakaan. Perpustakaan Unissula menangkap peluang tersebut, dengan mendirikan unit usaha kantin yang berdekatan dengan koleksi yang dimiliki oleh perpustakaan. Kantin tersebut menyediakan berbagai macam makanan dan minuman. Kantin tersebut bertujuan agar mahasiswa merasakan nyaman (betah) untuk berdiam diri di ruang perpustakaan ketika mengerjakan tugas. Unit usaha di Perpustakaan Unissula cukup unik karena menyatu dengan gedung perpustakaan sehingga pengunjung unit usaha sangat dekat dengan koleksi atau informasi yang mereka butuhkan. Informan merasakan nyaman ketika di unit usaha Perpustakaan Unissula, sehingga dapat juga digunakan sebagai meeting point, yakni tempat bertemu atau berkumpul, mengerjakan tugas kuliah, melakukan diskusi, ataupun bersantai. 


\section{2) Steker}

Teknologi informasi telah menjadi kebutuhan penunjang bagi mahasiswa. Para mahasiswa sebagian besar telah memiliki perangkat digital untuk mengerjakan tugas-tugas kuliah di kampus. Begitu juga halnya dengan Mahasiswa Unissula, mereka membawa handphone dan laptop untuk melakukan komunikasi dan untuk mengerjakan tugas perkuliahan mereka. Perangkat tersebut membutuhkan jaringan listrik untuk mengisi baterai/daya agar dapat dioperasikan. Untuk mendukung aktivitas mahasiswa dalam menggunakan handphone dan laptop, mencari informasi, dan menunjang diskusi, maka unit usaha Perpustakaan Unissula menyediakan steker di berbagai tempat, terutama di setiap meja makan dan minum di kantin perpustakaan.

\section{3) Wifi gratis}

Unit usaha kantin dan tempat fotokopi terintegrasi dengan layanan internet Perpustakaan Unissula. Bagi pengunjung unit usaha Perpustakaan Unissula dapat menikmati akses internet Iwifi secara gratis. Fasilitas tersebut bertujuan agar pengunjung lebih nyaman memanfaatkan fasilitas dan ruang perpustakaan untuk tempat diskusi.

Ruang publik di perpustakaan perlu didukung dengan lokasi yang strategis dan unit usaha yang memiliki harga lebih murah. Sebagaimana dikatakan Informan 2 bahwa “...pengunjung memilih dan memanfaatkan (salah satu) unit usaha di Perpustakaan Unissula tidak hanya lokasinya dekat dengan kuliah, tetapi harganya yang lebih murah...".

Para informan juga menyampaikan hal terkait dengan perbaikan unit usaha agar dapat dimanfaatkan secara maksimal oleh pemustaka. Sebagaimana yang dikatakan Informan 1 bahwa “...perpustakaan perlu lebih banyak mengadakan kegiatan di sekitar unit usaha yang tersedia, banyaknya kegiatan dari perpustakaan akan meningkatkan fungsinya sebagai tempat publik...”. Hal tersebut sesuai dengan konsep ruang publik di perpustakaan dalam wujud kemampuan dalam menyediakan informasi bagi perkembangan opini independen (Ariyani, 2015). Melalui kegiatan yang beragam, perpustakaan diharapkan mampu menghadirkan informasi terbaru kepada pemustaka disertai pembahasan melalui opini pakar yang dihadirkan.

Hal lain yang perlu dipertimbangkan oleh perpustakaan adalah luas ruangan. Sebagaimana dikatakan Informan 6, bahwa "...unit usaha yang ada perlu diperluas, agar lebih nyaman dan menarik lagi...". Luas ruangan ini dapat mengacu standar nasional perpustakaan, di mana luas ruang perpustakaan perguruan tinggi minimal $0,5 \mathrm{~m}^{2} /$ mahasiswa (PNRI, 2017).

\section{KESIMPULAN}

Berdasarkan hasil penelitian di atas dapat disimpulkan bahwa keberadaan unit usaha di Perpustakaan Unissula mampu memberikan kontribusi yang signifikan terhadap perwujudan perpustakaan perguruan tinggi sebagai public sphere. Melalui unit usaha yang tersedia, perpustakaan perguruan tinggi mampu menjadi meeting point, tempat berkumpul, berdiskusi, maupun menyalurkan aspirasi bagi pemustaka. Keberadaan unit usaha tersebut didukung dengan lokasi yang strategis serta harga yang mampu bersaing dengan unit usaha lain yang ada di luar perpustakaan. Penulis menyarankan agar perpustakaan perlu lebih banyak mengadakan kegiatan di sekitar unit usaha. Kegiatan tersebut sebagai sarana promosi perpustakaan untuk mengenalkan berbagai unit usaha yang ada di Perpustakaan Unissula. Selain itu, keberadaan unit usaha yang ada di perpustakaan perlu diperluas dan didesain semenarik mungkin agar mampu menciptakan suasana nyaman bagi pemustaka. Penulis mengucapkan terimakasih kepada Fakultas Ilmu Budaya sebagai penyandang dana penelitian serta para informan yang tidak dapat peneliti sebutkan satu persatu 


\section{DAFTAR PUSTAKA}

Ariyani, L.P.S. 2015. Perpustakaan Sebagai Ruang Publik: Perspektif Habermasian. Acarya Pustaka, l(1), 41-49.

Arya, D. 2011. Metamorfosa Paradigma Perpustakaan: Dari Non-Profit Sector Menuju Incoming Generatting Unit dengan Pemasaran Perpustakaan. EduLib, 1(1), 27-38.

Dewi, T.R. 2011. Konsep Perencanaan dan Perancangan Perpustakaan Umum sebagai Ruang Publik Kota Surakarta, Skripsi. Surakarta: UNS.

Istiarni, A. \& Triningsih, T. 2018. Jejak Pena Perpustakaan. Yogyakarta: Azyan Mitra Media.

Krismayani, I. 2016. Implementasi Pemikiran Jurgen Habermas terhadap Ilmu Perpustakaan dan Informasi. Jurnal Pustaka Budaya, 3(2), 18-24.

Muttaqin, A. 2010. Pemberdayaan Pedagang Angkringan untuk Membangun Perpustakaan Berbasis Kerakyatan. Visi Pustaka, 12(3).

Nasrullah, R. 2012. Internet dan Ruang Publik Virtual, Sebuah Refleksi atas Teori Ruang Publik Habermas. Jurnal Komunikator, 4(1), 33-45.

Opara, U. N. 2012. Strengthening Public Library Funding in Nigeria Through Innovative Activities. African Journal of Library, Archives \& Information Science, 22(2), 143-150.

PNRI. I. 2017. Peraturan Kepala Perpustakaan Nasional Republik Indonesia Nomor 13 Tahun 2017 Tentang Standar Nasional Perpustakaan Perguruan Tinggi. Jakarta.

Qomariyah, A.N. \& Rahmi, L. 2017. Upaya Perpustakaan Perguruan Tinggi dalam Menciptakan Ruang Publik: Kajian WiFi Zone Corner di Perpustakaan ITS. Pustakaloka, 9(11), 23-37.

Sugiyono. 2009. Metode Penelitian Kualitatif, Kuantitatif, dan R\&D. Bandung: Alfabeta

Sumaryanto, Y. 2008. Ruang Publik Jurgen Habermas dan Tinjauan atas Perpustakaan Umum di Indonesia. Tesis. Jakarta: Universitas Indonesia.

Widdersheim, M.M. 2017. Late, Lost, or Renewed? A Search for The Public Sphere in Public Libraries. Information Research, 22(1), 1-18. 